\title{
REVIEW \\ Coffee berry borer (Coleoptera: Curculionidae): An opening for fungi and toxins?
}

\author{
Josiane Bueno de Rezende ${ }^{1}$ (D), Marta Hiromi Taniwaki' ${ }^{\text {(D) }}$
}

'Instituto de Tecnologia de Alimentos/ITAL, Centro de Ciência e Qualidade de Alimentos/CCQA, Laboratório de Microbiologia, Campinas, SP, Brasil Corresponding author: bueno.josiane28@gmail.com, marta@ital.sp.gov.br

Received in April 9, 2020 and approved in November 9, 2020

\begin{abstract}
Coffee is one of the most consumed beverages in the world. Studies on coffee quality are important, because the occurrence of defective grains can affect its microbiological and sensory quality. The insect Hypothenemus hampei, when perfurating the fruits in the crop, causes coffee berry borer defects to reduce the weight of the grains and can also favor the entry of fungi, some of them toxigenic, that under ideal growth conditions are capable of producing toxins. The present article is a review of the general aspects of coffee, its defects, the coffee berry borer and the possible relationship with ochratoxigenic fungi and ochratoxin A production in coffee.
\end{abstract}

Key words: Coffee pest; Hypotenemus hampei; Endosulfan; Fungi; Ochratoxin A.

\section{INTRODUCTION}

The habit of coffee drinking is part of the routine of millions of people worldwide. The United States is the largest coffee consumer market in the world, followed by Brazil (United States Department of Agriculture - USDA, 2020). In 2017, consumption by Brazilians was estimated at 21.5 million bags of $60 \mathrm{~kg}$ of green coffee, with expectations of leading the world ranking by 2021 according to the (Empresa Brasileira de Pesquisa Agropecuária - EMBRAPA, 2017).

The quality of the beans at the end of processing influences the price achieved when sold on the market and therefore, defects in coffee beans are undesired because they decrease the coffee quality. One coffee defect is characterized by damage, caused by the coffee berry borer insect (Hypothenemus hampei - Coleoptera: Scolytidae), considered one of the main pests of coffee crops, which is responsible for perforations and damage to the fruits. Figure 1 features coffee beans infested by the coffee berry borer.

The chemical control of this pest applied to the crops, until the year 2012, was Endosulfan. In 2010 the National Health Surveillance Agency (ANVISA) issued a resolution ( $\mathrm{RDC} \mathrm{n}^{\circ}$ 28 , of August 9, 2010) in which it ordered the cancellation of the commercialization of this active ingredient from July 2013, because it is considered toxic to humans (Brasil, 2010). This ban caused coffee growers, without immediate alternatives to efficient chemicals, to find ways to control this pest.

Studies have shown that the coffee berry borer can facilitate the fungal growth inside the fruit and act as a vector in the transport of toxin-producing fungi spores (Da Silva et al., 2020; Vega; Infant; Johnson, 2015; Velmourougane;
Rajeev; Thirukonda, 2010). With good conditions for fungal growth, coffee can be a good substrate, and some fungi are able to produce mycotoxins such as ochratoxin A (OTA).

According to the data presented by (Taniwaki et al., 2014), defective coffee beans such as black and sour, were shown to be more susceptible to ochratoxigenic fungi: Aspergillus carbonarius, A. niger, A. westerdijkiae and $A$. ochraceus. Black and sour defective beans had the highest levels of OTA, compared to non-defective coffee beans and other defective beans such as green and black-green.

Few studies have reported coffee berry borer with ochratoxigenic fungi and ochratoxins in coffee, so the aims of this review are: to study the general aspects of coffee, its processing, defects in the beans and review the research that relate to the berry borer with the presence of ocratoxigenic fungi and ocratoxin A.

\subsection{General aspects of coffee}

The fruit of the coffee is composed of two seeds (endosperm), wrapped by silverskin (perisperm), parchment (endocarp), mucilage (mesocarp) and bark (exocarp) (Mesquita et al., 2016). Coffee species are grouped into two genera according basically to their flowering capacity: Coffea and Psilanthus (Bridson, 1987). All species of the genus Coffea probably originate from the intertropical forests of Africa and Madagascar (Couturon; Lashermes; Charrier, 1998). Fruits grouped to the genus Coffea have about 80 species and more than 100 varieties of coffee distributed in tropical and subtropical regions (Hamdouche et al., 2016). Among the species belonging to the genus Coffea, only two of them stand out in the world market: $C$. arabica and C. canephora, also known as arabica coffee and robust coffee, respectively. 


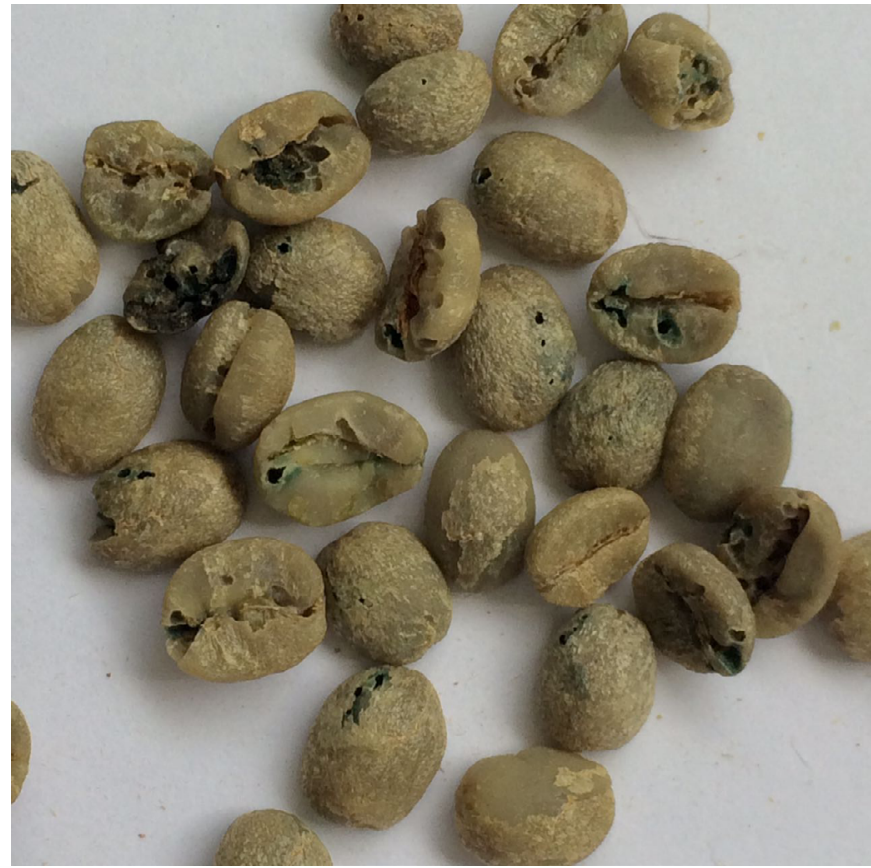

Figure 1: Coffee berry borer beans.

Coffee drink is usually prepared by infusing processed, roasted and ground grains. Due to the importance of these species worldwide, coffee is considered the second most valuable commodity in the world, after oil (Parras et al., 2007).

Brazil is the largest producer and exporter of coffee. In the 2020/21 harvest, total production was estimated at 61.6 million bags of green coffee, good biennial year (Companhia Nacional de Abasteciment - CONAB, 2020), while in the 2019 harvest the production was about 49 million (CONAB, 2019).

In Brazil, the species Coffea arabica accounts for about $81 \%$ of the area cultivated with coffee crops (CONAB, 2020). Arabica coffee is grown at altitudes of 600 to 2100 meters, and is the most marketed due to its flavor and aroma attributes. Robust coffee can be grown at low altitudes (100 to 1000 meters) and in a warm and humid climate, being used in blends with Arabica coffee and especially in the soluble coffee industry (Illy; Viani, 2005).

\subsection{Post-harvest processing}

In Brazil, coffee harvesting occurs during the months of May to September. The harvest by stripping, which is the most common, starts when more than $80 \%$ of the fruits are ripe, with the aim of obtaining a good quality coffee (Mesquita et al., 2016).

The harvest can be picked manually, semi-manually or with machines. In young crops, manual harvesting predominates and from the second harvest it can occur in a mechanized way, according to soil slope (Santinato et al.,
2015). Some coffee growers still use the fruits that fall onto the soil after harvesting the plant. This process is called sweeping, and is not recommended from the food safety point of view since it may favour the growth of ocratoxigenic fungi present in the soil, and impair the quality of the drink (Taniwaki et al., 2014).

After the harvest, the coffee can be processed by two methods: dry or wet. The choice depends on infrastructure, weather conditions and the consumer market, among others (Borém, 2008).

Using the dry method, after harvesting the fruit is washed and separated by density using a wash-separator. The heavier cherries (ripe fruits and immature) are separated from the others (raisins, dry fruits). After this process, whole beans are put on a concrete, asphalt or earth surface (this last one is not recommended) or suspended for natural drying, followed by mechanical dryers. The regular turning over of the fruits is important during the drying stage (Borém, 2008).

Regarding the wet method, the coffee harvested passes through the washer-separator, the ripe and green fruit proceed to the peeler, followed or not by the mucilage remover and drying. Alternatively, the ripe and green fruit comes out of the peeler and remains in fermentation tanks with the action of yeasts in order to obtain a hydrolysis of the mucilage. After this stage, the grains with parchment continue to dry in the drying yard and can complete drying in mechanical dryers (Borém, 2008).

After reaching the moisture content required, the coffee with parchment can be stored or proceed straight to the processing after dying is more recommended to leave the grains in parchment than without to preserve their quality (Selmar; Bytof; Knop, 2008). In Brazil, the Ministry of Livestock Agriculture and Supply (MAPA) recommends the maximum moisture content of $12 \%$ wet base (B.U.), for green coffee that will be stored (Brasil, 2011). With regard to water activity, the Association of Special Coffee of America suggests a safe value of 0.7 for the storage (Specialty Coffee Association of America - SCA, 2016).

\subsection{Defective coffee beans}

Coffee defects come from genetic, physiological or failing factors during processing, named intrinsic factors. The non-grain fractions are the extrinsic factors (Brasil, 2003). Extrinsic defects are bark, sticks and stones, while those of an intrinsic nature are green beans, black, green black, sour and brocades. The presence of these defects influence the classification of coffee by type, since they may be responsible for altering the taste of the beverage and causing loss to producers. Among these defects, brocade grains originate from the infestation of the coffee drill (Hypotenemus hampei) when drilling the fruit in the crop, allowing the fruit to fall into 
the soil resulting in possible large-scale losses (Teixeira; De Souza; Costa, 2006).

\subsection{Coffee berry borer (Hypothenemus hampei) and Endosulfan ban}

The coffee berry borer, Hypothenemus hampei (Ferrari) (Curculionidae: Scolytinae), is a beetle that infests the endosperm of fruits in the coffee crop causing insect damage. Coffee growers point it out as one of the main pests that attack the fruit, causing quantitative and qualitative losses in most coffee-producing crops in the world (Amézqueta et al., 2012). Figure 2 shows $H$. hampei inside the coffee fruit.

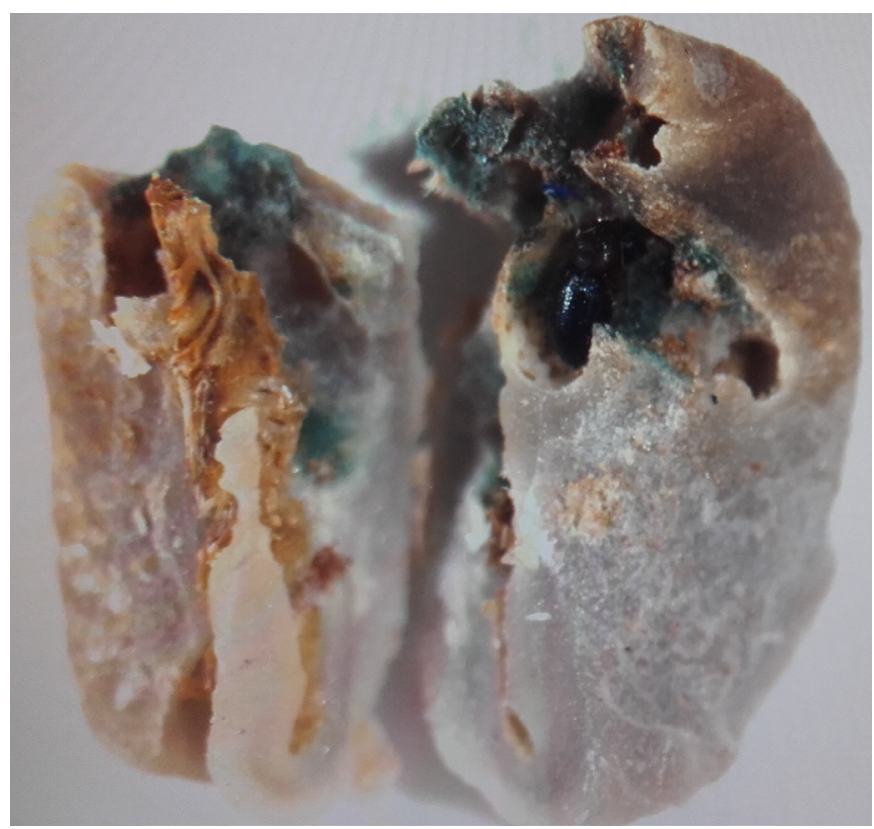

Figure 2: Longitudinal cut of coffee bean infested with Hypotenemus hampei.

The female insect is responsible for drilling the coffee fruit, green fruit, ripe and over-mature fruit, usually in the crown region. Inside the fruit, the insect forms galleries where it lays its eggs. After becoming adults, females are strongly attracted by other fruits due to the perception of odors, leaving the fruit and going to more attractive fruits (Damon, 2000; Rodríguez et al., 2017). In this period of drilling and formation of the galleries, the drill can deposit more than one hundred eggs and these proceed to the pre-pupa, pupa and adult insect stages within a period of one month or more. According to climatic conditions, the beetle tolerates a range of 15 to $32{ }^{\circ} \mathrm{C}$, with better development between 27 and 30 ${ }^{\circ} \mathrm{C}$ (Mariño et al., 2016; Jaramillo et al., 2009).

Coffee fruit is food for all phases of coffee berry borer development, providing a way for its growth and reproduction in medium to higher altitudes and differents optimal temperatures $\left(23^{\circ} \mathrm{C}-30^{\circ} \mathrm{C}\right)$ (Jaramillo et al, 2011). The insect spends most of its life cycle within the fruit, which makes it difficult for pesticides to act (Damon, 2000). Usually most pests occur more in crops in the shade than in crops exposed to the sun (Mariño et al., 2016).

Drilling caused by the coffee berry borer can facilitate the entry of bacteria and fungi into the fruit. Greenish coloration in grains can be due to the mechanical action of perforation and oxidation, as well as the presence of fungi and bacteria (Carrion; Bonet, 2004).

Until 2012, the main insecticide used to control the coffee berry borer was Endosulfan $(6,7,8,9,10$, 10-hexachloro-1, 5, 5a, 6, 9, 9a-hexahydro-6, 9 methano-2, 4, 3-benzodiexathiepin-3-oxide), its action is of contact and ingestion, causing the death of insects and its application occurs in the aerial parts of the plant (Plata-Rueda, 2019), to the drill combat in coffee, this insecticide is also capable of fighting other pests in agriculture (Pozo et al., 2011). Studies have show that endosulfan is present in marine mammals and is very persistent in the environment (Weber et al., 2010). For the coffee berry borer, The World Health Organization (WHO) classified Endosulfan in Class II, that is, moderate risk to human health (World Health Organization, 2009). However, the National Health Surveillance Agency (ANVISA) classified it as class I, extremely toxic (Brasil, 2010) banning its use from 2013, because it was considered a toxic product for humans (Brasil, 2010). Although the ban on trading Endosulfan had already been announced in 2010, most coffee growers did not prepare for an alternative to combat the coffee berry borer, and from 2013 there has been an increase in the rejection of coffee drilled by the coffee industry.

Among the measures of cultural control of this pest is the complete removal of the fruit of the plant during the harvest, allowing for a decrease of the focal points of drill infestation. However, this practice is not very common among coffee growers as it increases the process cost (Cure et al., 2020).

Recently, manufacturers of chemicals used in agriculture have launched products that fight coffee berry drill which have different active principles and modes of action, some of them already registered with the Ministry of Agriculture (MAPA) (Table 1) (Agrofit, 2020). Although these chemical agents are available for marketing in drill control, they do not have the same efficacy compared to Endosulfan.

Kiran, Shenoy and Venkatesha (2019) demonstrate that the incidence of coffe berry borer and toxigenic fungi may be controlled using radiation processing in treatment post-harvest coffee. 
Table 1: Commercial products used to combat the coffee berry borer.

\begin{tabular}{|c|c|c|c|}
\hline Commercial Product & Active ingredient & Hazard classification & $\begin{array}{c}\text { Registration } \\
\text { Certificate Update }\end{array}$ \\
\hline Alverde & Metaflimizona & Product unlikely to cause acute damage & 2017 \\
\hline Azamax & Azadiractina & Product unlikely to cause acute damage & 2017 \\
\hline Benevia & Ciantraniliprole & Unclassified product & 2017 \\
\hline Bio broca & Methanol + Ethanol & Unclassified product & 2017 \\
\hline Chloromo $480 \mathrm{EC}$ & Clorpirifós & Highly Toxic Product & 2020 \\
\hline Ciclone 48 EC & Clorpirifós & Low Toxic Product & 2017 \\
\hline Clorpiri 480 EC & Clorpirifós & Moderately Toxic Product & 2020 \\
\hline Clorpirifós Fersol 480 EC & Clorpirifós & Moderately Toxic Product & 2017 \\
\hline Clorpirifós Nortox EC & Clorpirifós & Low Toxic Product & 2019 \\
\hline Clorpirifós Poland $480 \mathrm{E}$ & Clorpirifós & Highly Toxic Product & 2017 \\
\hline Clorpirifos Sabero $480 \mathrm{EC}$ & Clorpirifós & Highly Toxic Product & 2017 \\
\hline Curbix 200 SC & Etiprole & Product unlikely to cause acute damage & 2017 \\
\hline Instivo & Clorantraniliprole + Abamectina & Low Toxic Product & 2017 \\
\hline Klorpan $480 \mathrm{EC}$ & Clorpirifós & Moderately Toxic Product & 2017 \\
\hline Lorsban $480 \mathrm{BR}$ & Clorpirifós & Moderately Toxic Product & 2017 \\
\hline Plethora BR & Indoxacarbe + Novalurom & Product unlikely to cause acute damage & 2020 \\
\hline Prez & Acetamiprido + Bifentrina & Moderately Toxic Product & 2017 \\
\hline Pyrinex 480 EC & Clorpirifós & Low Toxic Product & 2017 \\
\hline Sperto & Acetamiprido + Bifentrina & Moderately Toxic Product & 2017 \\
\hline Tracer & Espinosade & Unclassified product & 2017 \\
\hline Trebon $100 \mathrm{SC}$ & Etofenproxi & Product unlikely to cause acute damage & 2017 \\
\hline Verimark & Ciantraniliprole & Unclassified product & 2017 \\
\hline Verismo & Metaflimizona & Product unlikely to cause acute damage & 2017 \\
\hline Voliam Targo & Abamectina + Clorantraniliprole & Low Toxic Product & 2017 \\
\hline Wild & Clorpirifós & Highly Toxic Product & 2018 \\
\hline
\end{tabular}

\subsection{Ochratoxigenic fungi in coffee}

Coffee is susceptible to infection by ocratoxigenic fungi, mainly due to failures during the post-harvest process (Taniwaki et al., 2003). Long periods in which coffee is bagged after harvest until drying, rainfall during the drying stage in farm yards, lack of grain spreading in the farm yards and inadequate storage, are fundamental factors for the growth of potentially ocratoxin-producing fungi (Urbano et al., 2001, Taniwaki et al., 2019). The main species of ocratoxin A producing fungi are: A. westerdijkae, A. ochraceus, A. carbonarius and A. niger (Magnani et al., 2005; Noonim et al., 2008; Taniwaki et al., 2003).

Taniwaki et al. (2003) analyzed a total of 408 coffee samples collected in different processing stages such as: from the coffee tree (cherry and raisins), soil raisins, drying in farm yard and storage. In this work it was found that the coffee left on the soil as well as inadequate drying and storage conditions, contributed to a greater infection by ocratoxigenic fungi. It was also verified that the cherry coffee collected from the coffee tree had a low infection of ocratoxigenic fungi, showing that the infection occurs after harvest.

Geremew et al. (2016) studied the mycobiota of coffee stored in Ethiopia and found that the strains of $A$. westerdijkae had higher potential for ochratoxin A production than $A$. ochraceus.

\subsection{Ocratoxin A in coffee}

Ocratoxin A (OTA) is a secondary metabolite produced by some species of filamentous fungi of Aspergillus, mainly A. ochraceus, A. westerdijkae, A. carbonarius and Penicillium species such as $P$. verrucosum and $P$. nordicum (Pitt; Hocking, 2009). In temperate climates the occurrence of OTAcontaminated foods is usually due to infection by $P$. verrucosum and $P$. nordicum. In tropical and sub tropical climates toxigenic species of the genus Aspergillus predominate (Pitt, 2000).

OTA is nephrotoxic and possibly carcinogenic and teratogenic in animal cells (Galvano et al., 2005). The International Agency for Cancer Research (IARC) classified 
ocratoxin A in Group 2B, considered potentially carcinogenic in humans (International Agency for Research on Cancer IARC, 1993).

The presence of ocratoxin $\mathrm{A}$ in green coffee has been reported in various parts of the world. Pardo et al. (2004) analyzed samples of arabica and robust green coffee from different producing countries, finding levels of 1.3 to $31.5 \mu \mathrm{g}$ $\mathrm{kg}^{-1}$ without significant differences between the two coffee species. Batista et al. (2009) conducted a study with different fractions of coffee during dry and wet processing. It was verified that in green fruit, cherries, raisins and peeled cherries there was a low presence of OTA while in the ground coffee, the levels were higher than $100 \mu \mathrm{g} \mathrm{kg}^{-1}$.

In Brazil, ANVISA established the maximum limit of ochratoxin A of $10 \mu \mathrm{g} \mathrm{kg}^{-1}$ in roasted coffee (ground and grain) and soluble coffee (Brasil, 2011), while in the European Union, the maximum limit of ochratoxin A in roasted coffee and soluble coffee is $5 \mu \mathrm{g} \mathrm{kg}^{-1}$ and $10 \mu \mathrm{g} \mathrm{kg}^{-1}$, respectively (European Commission, 2004).

Research shows that after coffee roasting, ochratoxin A can be reduced from $93 \%$ to $13 \%$ (Pérez de Obanos; González-Peñas; López de Cerain, 2005). Ferraz et al. (2010) found a reduction from 8 to $98 \%$ during the roasting process at a temperature of 180 to $240{ }^{\circ} \mathrm{C}$ and this reduction depends on the roasting point.

\subsection{Fungi and ochratoxin A in coffee beans infected with the coffee berry borer}

Few studies have reported the presence of ocratoxigenic fungi with the coffee berry borer. Pérez et al. (2003) analyzing the mycobiota associated with the coffee berry borer and the galleries formed in the fruit, of three crops in Mexico, found the genera Fusarium spp, Penicillium spp, and Aspergillus spp. In this work they isolated 187 strains of fungi in the bodies of the insects, while in galleries only 25 strains of four different genera were isolated. The authors did not identify the fungi at species level, thus being unable to verify whether toxigenic fungi were present. According to the authors, the climatic conditions of the region affected the mycobiota present in the insect and in the galleries.

A study conducted in Mexico, between 1999 and 2002, identified several species of fungi in the coffee berry borer, and also the damaged fruit and the galleries with the main species being: A. niger, A. flavus, Penicillium spp, Cladosporium spp e Fusarium solani (Carrion; Bonet, 2004).

When comparing coffee beans infected with the coffee berry borer and the aerial parts of $C$. canephora, Gama et al. (2005) isolated 110 and 91 fungal strains from brocade grains that fell onto the soil and those that were in the plant, respectively, represented by the genus Fusarium, Geotrichum, Penicillium and Aspergillus. Later, the mycobiota of the coffee berry borer was determined from C. canephora and parts of the body such as the cuticle, oral tract, prothorax, digestive tract and stools. In this study, a total of 201 fungi were isolated, especially the genus Fusarium, Penicillium, Geotrichum and Aspergillus, both in structures and in galleries (Gama et al., 2006). Again, the species were not identified, thus not allowing to say whether there were toxigenic species.

Vega, Mercadie and Dowd (1999) found that females of the coffee berry borer emerging from fruits from various producing regions were vectors of spores of $A$. ochraceus, $A$. flavus and $A$. niger. In a study on the mycobiota of the coffee berry borer adult emerged from the fruits, conducted in two countries of Africa (Uganda and Benin), it was found that in Uganda, $5.3 \%$ of the insects were infected by $A$. ochraceus and in Benin, $17.4 \%$. The strains of $A$. ochraceus were potentially producers of ochratoxin A (Vega; Mercadier, 1998). However, these authors (Vega; Mercadier, 1998; Vega; Mercadie; Dowd, 1999) did not analyze the content of ochrotoxin A in the coffee samples.

In India, Velmourougane, Rajeev and Thirukonda (2010) compared ocratoxin A contamination in arabica and robust coffee beans infested by the coffee berry borer and uninfested beans over a three-year period. Brocade fruits were collected from: soil, left in plants, freshly harvested and non-brocade beans. An average contamination was observed, referring to the three years, of $8.80 \mu \mathrm{g} \mathrm{kg}^{-1}$ of OTA in brocade grains that had contact with the soil, followed by the brocade grains that remained in the plants $\left(4.35 \mu \mathrm{g} \mathrm{kg}^{-1}\right.$ of OTA) and newly harvested brocade fruits $\left(2.35 \mu \mathrm{g} \mathrm{kg}^{-1}\right.$ of OTA $)$ in arabica and robust coffee.

Vargas et al. (2005) studied the influence of coffee processing and defects on the occurrence of ochratoxin A. In this study, 762 samples mainly of arabica coffee from different regions of Brazil were collected. It was found that $66.7 \%$ of the samples contained at least nine types of defects with: sour, brocade beans, black and malformed being the ones that most contributed to the occurrence and OTA levels in coffee. However, these authors (Vargas et al., 2005) did not study the level of infection by ocratoxigenic fungi in these samples.

Da Silva et al. (2020), investigated the incidence of toxigenic fungi and ocratoxin A in coffee beans infected with the coffee berry borer. The authors showed that the insect may help the greater level of toxigenic fungi and ochratoxin A.

\section{CONCLUSIONS}

It is important to consider that the infestation caused by the coffee berry borer in crops, in addition to causing quantitative losses to producers, can also reduce the quality of the grains. Besides that, the presence of the coffee berry borer added to the processing failures along the chain, can lead to the development of fungi and production of toxins, such as OTA. The reduction of coffee berry borer infestation can be 
minimized by adopting Good Agricultural Practices in crops, and Good Practices during the processing of the entire chain are measures that help prevent the presence of fungi and toxins in coffee, improving the beverage quality.

\section{ACKNOWLEDGEMENTS}

The authors thank the Agribusiness Research Development Foundation (FUNDEPAG) for the grant given to J.B.R. and the National Council for Scientific and Technological Development $(\mathrm{CNPq})$ for the grant given to M.H.T. (Process 303732/2018-0) and Coordenadoria de Aperfeiçoamento de Pessoal do Ensino Superior (CAPES).

\section{REFERENCES}

AGROFIT. Sistema de agrotóxicos fitossanitários. Ministério da agricultura, pecuária e abastecimento. 2020. Available in: <http://agrofit.agricultura.gov.br/agrofit_cons/principal_ agrofit_cons $>$. Access in: October, 13, 2020.

AMÉZQUETA, S. et al. OTA-producing fungi in foodstuffs: A review. Food Control, 26(2):259-268, 2012.

BATISTA, R. L. et al. Ochratoxin A in coffee beans (Coffea arabica $\mathrm{L}$.) processed by dry and wet methods. Food Control, 20(9):784-790, 2009.

BORÉM, F. M. Pós-colheita do café. Lavras: Editora UFLA, 2008, 631p.

BRASIL. Ministério da Agricultura, Pecuária e Abastecimento. Instrução normativa $n^{\circ} 8$, de 11 de junho de 2003. Regulamento técnico de identidade e de qualidade para a classificação do café beneficiado grão cru. Available in: <http://www.sapc.embrapa.br/arquivos/ consorcio/legislacao/Instrucao_Normativa_n_8.pdf $>$. Access in: November, 16, 2020.

BRASIL. Ministério da Agricultura, Pecuária e Abastecimento. Instrução normativa no 29, de 8 de junho de 2011. Requisitos técnicos obrigatórios ou recomendados para certificação de unidades armazenadoras em ambiente natural. Available in: $<$ http:// sistemasweb.agricultura.gov.br/sislegis/action/detalhaAto. do? method $=$ visualizarAtoPortalMapa\&chave $=$ 677165707>. Access in: June, 04, 2020.

BRASIL. Ministério da Saúde. Agência Nacional de Vigilância Sanitária. Resolução no 28, de 9 de agosto de 2010. Regulamento técnico para o ingrediente ativo endossulfam em decorrência da reavaliação toxicológica. Available ai: <http://www.adapar.pr.gov.br/sites/adapar/arquivos restritos/files/documento/2020-10/lf_6_resolucao_rdc_28_ de_2010.pdf $>$. Access in: November, 16, 2020.
BRASIL. Ministério da Saúde. Agência Nacional de Vigilância Sanitária. Resolução n ${ }^{\circ}$, de 18 de fevereiro de 2011. Dispõe sobre limites máximos tolerados (LMT) para micotoxinas em alimentos. Available in: $<$ http://bvsms.saude.gov.br/bvs/saudelegis/anvisa/2011/ res0007_18_02_2011_rep.html >. Access in: January, 10, 2020.

BRIDSON, D. M. Nomenclatural notes on psilanthus, including coffea sect. Paracoffea (Rubiaceae Tribe Coffeeae). Kew bulletin, 42(2):453-460, 1987.

CARRION, G.; BONET, A. Mycobiota associated with the coffee berry borer (Coleoptera: Scolytidae) and its galleries in fruit. Annals of the Entomological Society of America, 97(3):492-499, 2004.

COMPANHIA NACIONAL DE ABASTECIMENTO CONAB. Acompanhamento da safra brasileira: Café monitoramento agrícola - Safra 2019. Available in: $<$ https:/www.conab.gov.br/component/k2/item/ download/28519_1451c80af85a09013032c62 c38317623>. Access in: October, 13, 2020.

\section{COMPANHIA NACIONAL DE ABASTECIMENTO} - CONAB. Acompanhamento da safra brasileira: Café monitoramento agrícola - Safra 2020. Available in: <https://www.conab.gov.br/component/k2/item/ download/30380_d1e1f36c2356b81e8a385cd24f05993b>. Access in: October, 13, 2020.

COUTURON, E.; LASHERMES, P.; CHARRIER, A. First intergeneric hybrids (Psilanthus ebracteolatus Hiern $\times$ Coffea arabica L.) in coffee trees. Canadian Journal of Botany, 76(3):542-546, 1998.

CURE, J. R. et al. The coffee agroecosystem: Bioeconomic analysis of coffee berry borer control (Hypothenemus hampei). Scientific Reports, 10(1):112,2020 .

DA SILVA, S. A. et al. Fungi associated to beans infested with coffee berry borer and the risk of ochratoxin A. Food Control, 113:e107204, 2020.

DAMON, A. A review of the biology and control of the coffee berry borer, Hypothenemus hampei (Coleoptera: Scolytidae). Bulletin of Entomological Research, 90(6):453-465, 2000.

\section{EMPRESA BRASILEIRA DE PESQUISA} AGROPECUÁRIA - EMBRAPA. Tendências do mercado de cafés. 2017. Available in: $<$ http:// consorciopesquisacafe.com.br/arquivos/consorcio/ consumo/tendencias_do_mercado_cafe_2017.pdf $>$. Access in: May, 02, 2020 . 
EUROPEAN COMMISSION. EU rules on ochratoxin a extended to coffee, wine and grape juice. 2004. Availabe it: $<$ https://ec.europa.eu/commission/ presscorner/detail/en/IP_04_1215> Access in: January, 01,2020

FERRAZ, M. B. M. et al. Kinetics of ochratoxin a destruction during coffee roasting. Food Control, 21(6):872-877, 2010 .

GALVANO, F. et al. Mycotoxins in the human food chain. The mycotoxin blue book, 1:187-224, 2005.

GAMA, F. D. C. et al. Influência do ambiente na diversidade de fungos associados a Hypothenemus hampei (Ferrari) (Coleoptera, Scolytidae) e frutos de Coffea canephora. Arquivos do Instituto Biológico, 72(3):359-364, 2005.

GAMA, F. D. C. et al. Diversity of filamentous fungi associated with Hypothenemus hampei (Ferrari) (Coleoptera: Scolytidae) and its galleries in berries of Coffea canephora (Pierre). Neotropical Entomology, 35(5):573-578, 2006.

GEREMEW, T. et al. Occurrence of toxigenic fungi and ochratoxin a in Ethiopian coffee for local consumption. Food Control, 69:65-73, 2016.

HAMDOUCHE, Y. et al. Discrimination of post-harvest coffee processing methods by microbial ecology analyses. Food Control, 65:112-120, 2016.

ILLY, A.; VIANI, R. Espresso coffee: The science of the quality. 2 Ed. London: Elsevier Academic Press, 2005, 398 .

\section{INTERNATIONAL AGENCY FOR RESEARCH ON} CANCER - IARC. Some naturally occurring substances: Food items and constituents, heterocyclic aromatic amines and mycotoxins. 1993. Available in: $<$ https://www.ncbi.nlm.nih.gov/books/NBK513620/\#>. Access in: April, 09, 2020.

JARAMILLO, J. et al. Thermal tolerance of the coffee berry borer Hypothenemus hampei: predictions of climate change impact on a tropical insect pest. PloS one, 4(8):e6487, 2009.

JARAMILLO, J. et al. Some like it hot: The influence and implications of climate change on coffee berry borer (Hypothenemus hampei) and coffee production in East Africa. PloS one, 6(9):e24528, 2011.

KIRAN, R.; SHENOY, K. B.; VENKATESHA, M. G. Effect of gamma radiation as a post-harvest disinfestation treatment against life stages of the coffee berry borer, Hypothenemus hampei (Ferrari) (Coleoptera:
Curculionidae). International journal of Radiation Biology, 95(9):1301-1308, 2019.

MAGNANI, M. et al. Molecular identification of Aspergillus spp. isolated from coffee beans. Scientia Agricola, 62(1):45-49, 2005.

MARIÑO, Y. A. et al. Sun vs. shade affects infestation, total population and sex ratio of the coffee berry borer (Hypothenemus hampei) in Puerto Rico. Agriculture, Ecosystems \& Environment, 222:258-266, 2016.

MESQUITA, C. M. et al. Manual do café: Colheita e Preparo (Coffea arabica L.). Belo Horizonte: EMATERMG, 2016. 52p.

NOONIM, P. et al. Isolation, identification and toxigenic potential of ochratoxin A-producing Aspergillus species from coffee beans grown in two regions of Thailand. International journal of food microbiology, 128(2):197202, 2008.

PARDO, E. et al. Occurrence of ochratoxigenic fungi and ochratoxin a in green coffee from different origins. Food Science and Technology International, 10(1):45-49, 2004.

PARRAS, P. et al. Antioxidant capacity of coffees of several origins brewed following three different procedures. Food Chemistry, 102(3):582-592, 2007.

PÉREZ DE OBANOS, A.; GONZÁLEZ-PEÑAS, E.; LÓPEZ DE CERAIN, A. Influence of roasting and brew preparation on the ochratoxin a content in coffee infusion. Food Additives and Contaminants, 22(5):463-471, 2005.

PÉREZ, J. et al. Mycobiota associated with the coffee berry borer (Hypothenemus hampei) in Mexico. Mycological Research, 107(7):879-887, 2003.

PITT, J. I. Toxigenic fungi and mycotoxins. British Medical Bulletin, 56(1):184-192, 2000.

PITT, J. I.; HOCKING, A. D. Fungi and food spoilage. 3rd ed. New York: Springer, 2009. 519p.

PLATA-RUEDA, A. et al. Exposure to cyantraniliprole causes mortality and disturbs behavioral and respiratory responses in the coffee berry borer (Hypothenemus hampei). Pest Management Science, 75(8):2236-2241, 2019.

POZO, K. et al. Assessing seasonal and spatial trends of persistent organic pollutants (POPs) in Indian agricultural regions using PUF disk passive air samplers. Environmental Pollution, 159(2):646-653, 2011. 
RODRÍGUEZ, D. et al. Coffee agroecosystem model: III. Parasitoids of the coffee berry borer (Hypothenemus hampei). Ecological Modelling, 363:96-110, 2017.

SANTINATO, F. et al. Mechanized harvesting of first crop of coffee. Revista Brasileira De Engenharia Agricola e Ambiental, 19(11/12):1215-1219, 2015.

SELMAR, D.; BYTOF, G.; KNOPP, S. E. The storage of green coffee (Coffea arabica): Decrease of viability and changes of potential aroma precursors. Annals of Botany, 101(1): 31-38, 2008.

\section{SPECIALTY COFFEE ASSOCIATION OF AMERICA}

- SCAA. Water Activity SCAA Standard. 2016. Available in: $<$ https://sca.coffee/research/coffeestandards $>$. Access in: November, 16, 2020.

TANIWAKI, M. H. et al. The source of ochratoxin a in Brazilian coffee and its formation in relation to processing methods. International Journal of Food Microbiology, 82(2):173-179, 2003.

TANIWAKI, M. H. et al. Ochratoxigenic fungi and ochratoxin a in defective coffee beans. Food Research International, 61:161-166, 2014.

TANIWAKI, M. H. et al. Understanding mycotoxin contamination across the food chain in Brazil: Challenges and opportunities. Toxins, 11(7):411, 2019.

TEIXEIRA, C. A. D.; DE SOUZA, O.; COSTA, J. N. M. Conilon coffee berries bored by Hypothenemus hampei (Ferrari) (Coleoptera: Scolytidae): what matters if they drop down during the fruiting phase? Neotropical Entomology, 35(3):390-394, 2006.

UNITED STATES DEPARTMENT OF AGRICULTURE USDA. Coffee: World markets and trade. 2020. Available in: <https://www.fas.usda.gov/data/coffee-world-marketsand-trade $>$. Access in: October, 13, 2020.
URBANO, G. R. et al. Occurrence of ochratoxin A-producing fungi in raw Brazilian coffee. Journal of Food Protection, 64(8):1226-1230, 2001.

VARGAS, E. A. et al. Influence of coffee processing and defects on the incidence and occurrence of ochratoxin A. In: PARK, D. L. et al. XI International IUPAC symposium on mycotoxins and phycotoxins. p.84-85, 2005.

VEGA, F. E.; INFANTE, F.; JOHNSON, A. J. The genus hypothenemus, with emphasis on $\mathrm{H}$. hampei, the coffee berry borer. In: VEGA, F. E.; HOFSTETTER, R. W. (Eds), Bark Beetles: Biology and ecology of native and invasive species. Academic Press. p.427-494, 2015.

VEGA, F. E.; MERCADIER, G.; DOWD, P. F. Fungi associated with the coffee berry borer Hypothenemus hampei (Ferrari) (Coleoptera: Scolytidae). Proceedings of the 18th International Scientific Colloquium on Coffee, Helsinki, August 1999. Association Scientifique Internationale du Café (ASIC), p.229-238, 1999.

VEGA, F. E.; MERCADIER, G. Insects, coffee and ochratoxin a. The Florida Entomologist, 81(4):543-544, 1998.

VELMOUROUGANE, K.; RAJEEV, B.; THIRUKONDA, G. N. Coffee berry borer (Hypothenemus hampei) - A vector for toxigenic molds and ochratoxin a contamination in coffee beans. Foodborne Pathogens and Disease, 7(10):1279-1284, 2010.

WEBER, J. et al. Endosulfan, a global pesticide: A review of its fate in the environment and occurrence in the Arctic. Science of the Total Environment, 408(15):29662984, 2010.

\section{WORLD HEALTH ORGANIZATION. The WHO} recommended classification of pesticides by hazard and guidelines to classification 2009. Available in: $<\mathrm{https}$ ://apps. who.int/iris/bitstream/handle/10665/44271/9789241547963 eng.pdf? sequence $=1 \&$ isAllowed $=y>$. Access in: January, 01, 2020. 